\title{
1. Energy justice: frameworks for energy law and policy
}

\section{Raya Salter, Carmen G. Gonzalez, and Elizabeth Ann Kronk Warner}

\section{INTRODUCTION}

Energy law has grown rapidly in the past three decades as a specialization within environmental law and natural resources law. Dozens of law schools in the United States and abroad offer courses and have developed programs in the energy area, a trend that is expected to increase. This is in no small part due to a renewed global focus on the need to both curb the fossil fuel use that contributes to climate change and modernize existing aging energy infrastructure.

Between January 2016 and March 2018, 175 countries ratified the Paris Agreement and made commitments to reduce greenhouse gas emissions. In 2016, "[t]he electricity sector edged ahead of the fossil fuel supply sector to become the largest recipient of [global] energy investment" for the first time ever. ${ }^{1}$ Global "[i]nvestment in new renewablesbased power, at USD 297 billion [was] ... the largest area of electricity spending."2 Global investment in electricity networks and energy storage reached an all-time high of US\$277 billion in $2016 .^{3}$ In the technology and policy arenas, there is now tremendous momentum towards building smarter and cleaner energy infrastructure.

It is in this context of climate change and historic energy infrastructure investment that energy justice, broadly, calls for a moral examination of energy systems from an energy law perspective. Despite the increased attention being given to energy law, the clean energy transition, and grid modernization, the concept of energy justice is relatively new. Although

\footnotetext{
1 International Energy Agency, World Energy Investment 2017 Executive Summary 2 (2017), available at www.iea.org/Textbase/npsum/WEI2017SUM.pdf.

2 Ibid. at 3.

3 Ibid.
} 
the term has been used in practice for almost a decade, it was not until 2013 that the concept of energy justice began to be fully developed within the academic sphere. ${ }^{4}$ Accordingly, energy justice remains undertheorized, and, perhaps more importantly, few have considered how theories of energy justice might be applied practically.

This book, among the first of its kind, addresses a range of energy justice regulatory challenges from the perspective of international law, US law, and foreign domestic law. In doing so, the chapters that follow both illuminate the theory of energy justice and, in many cases, explain how energy justice policy might be applied in practice. In this regard, the book fills an existing gap in the scholarly literature on energy justice.

Why focus on energy justice? The concept of energy justice refines and expands our legal understanding of how we plan for, invest in, and regulate energy. A just global energy system is one that is safe, reliable, fair, affordable, and also sustainable for current and future generations and the natural world. Importantly, energy justice also necessitates an energy path forward that is restorative, or minimizes and reverses the cumulative impacts of energy systems at local, regional, and global levels. This includes adverse impacts on the planet's ecosystems and on the communities disproportionately burdened by the impacts of energy production, distribution, and consumption. The need for restoration is critical, as energy justice, above all, seeks just outcomes.

An energy justice perspective is also helpful when considering responses to the negative impacts of climate change. Climate change, once seen as a problem of the future, is now a daunting contemporary challenge. ${ }^{5}$ Energy justice calls for energy theory and practice that can address the needs and priorities of those now experiencing the negative impacts of climate change with the most intensity. This book recognizes that we must transition away from fossil fuels with urgency. In developing energy transition strategies, however, a pure economic focus, or even a pure greenhouse gas mitigation focus, cannot yield just results.

It is important to note that the underpinnings of energy justice theory are still in development. To date, two main definitions of energy justice have emerged. Both build upon justice theories that, in energy advocacy, have traditional roots in environmental justice and climate justice.

4 Raphael J. Heffron and Darren McCauley, The Concept of Energy Justice Across the Disciplines, 105 ENERGY POL'y 658, 659 (2017).

5 See generally US Global Change Research Program, 1 Climate Science Special Report: Fourth National Climate Assessment (2017) (describing how the United States is currently experiencing the effects of climate change). 
The first definition advances the idea that energy justice is composed of three central tenets, namely distributive, procedural, and recognition justice. ${ }^{6}$ In the energy space, both distributive and procedural justice are closely identified with the theory and practice of the environmental justice movement. Distributive justice examines the allocation of the costs and benefits of the energy system across society. ${ }^{7}$ Procedural justice calls for processes that meaningfully and fairly engage stakeholders in an inclusive and non-discriminatory way. ${ }^{8}$ Recognition justice, while closely linked to procedural justice, seeks fair representation, including equal political rights and freedom from denigration or disrespect based on poverty, race, culture, ethnicity, gender, or other characteristics. ${ }^{9}$

The second energy justice definition emphasizes eight core principles: availability, sustainability, affordability, due process, transparency and accountability, intra-generational equity, inter-generational equity, and responsibility. ${ }^{10}$ Availability, affordability, and intra-generational equity require the eradication of energy poverty and the provision of high quality energy services on an equitable basis to all. ${ }^{11}$ Due process, transparency, and accountability can be implemented through a variety of mechanisms, including social and environmental impact assessments; free, prior and informed consent procedures; extractive industry transparency standards; and international standards for the reporting of energy subsidies. ${ }^{12}$ Sustainability and inter-generational equity call for energy

6 See generally Darren McCauley et al., Advancing Energy Justice: The Triumvirate of Tenets, 32 INT'L ENERGY L. REV. 107 (2013).

7 See generally Gordon Walker, Beyond Distribution and Proximity: Exploring the Multiple Spatialities of Environmental Justice, 41 ANTIPODE 614, 614-36 (2009); Benjamin K. Sovacool and Michael H. Dworkin, Global Energy Justice: Problems, PRinCIPLES, AND PRACTICES 13 (2014).

8 See Sovacool and Dworkin, Global EnERGy Justice, supra note 7, at 13 .

9 See McCauley et al., Advancing Energy Justice, supra note 6, at 108; David Schlosberg, The Justice of Environmental Justice: Reconciling Equity, Recognition, and Participation in a Political Movement, in Moral AND POLITICAL REASONING IN ENVIRONMENTAL PRACTICE 89-92 (Andrew Light and Avner De-Shalit, eds., 2003) (describing recognition justice as implicating practices of cultural domination and disrespect).

10 See Benjamin K. Sovacool et al., Energy Decisions Reframed as Justice and Ethical Concerns, 1 NATURE ENERGY 1, 3 (2016).

11 See ibid. at 5 table 2 (illustrating the energy justice decision-making framework).

12 See ibid. 
systems that respect ecological limits and the rights of future generations. ${ }^{13}$ Finally, responsibility refers to the obligation of all nations "to protect the natural environment and reduce energy-related environmental threats."14 These eight principles can offer practical guidance to legislators, regulators, and the public in the formulation and implementation of energy law and policy.

Drawing upon several of these principles, Sovacool and Dworkin define an energy just world as:

one that equitably shares both the benefits and burdens involved in the production and consumption of energy services, as well as one that is fair in how it treats people and communities in energy decision-making. In other words, we see importance to both substantive outcomes and decisional procedures. Energy justice, thus, involves the right of all to access energy services, regardless of whether they are citizens of more or less greatly developed economies. It encompasses how negative environmental and social impacts related to energy are distributed across space and time, including human rights abuses and the access that disenfranchised communities do or should have to remedies. Energy justice ensures that energy permitting and siting do not infringe on basic civil liberties and that communities are meaningfully informed and represented in energy decisions. ${ }^{15}$

The concept of energy justice presented in the chapters that follow incorporates elements of these definitions, but also sheds additional light on the intersection of energy justice with environmental justice, human rights, climate justice, and indigenous rights. Related closely to these intersections is the idea that the displacement of vulnerable communities, involuntary resettlement, the imposition of inequitable pollution burdens, and energy poverty are key energy problems that need to be addressed through an energy justice framework. Two of the chapters explore the relationship between energy justice and energy democracy. Finally, several of the chapters reflect on how these theories might be transferred to practice-how energy justice becomes a delivered outcome through law and policy.

\footnotetext{
13 See ibid.

14 Ibid.

15 Sovacool and Dworkin, Global EnERgy Justice, supra note 7, at 5.
} 


\section{INTERSECTION WITH ENVIRONMENTAL JUSTICE}

One of the intersections considered by this book is the link between the environmental justice movement and energy justice. ${ }^{16}$ Uma Outka's chapter, "Fairness in the low-carbon shift: learning from environmental justice" (Chapter 2), does exactly this. The environmental justice movement in the United States forged a pivotal connection among concerns for social justice, civil rights, and environmental protection. Today, as climate change drives a shift in the energy sector away from fossil fuels and toward low-carbon resources, calls for "energy justice" and "climate justice" expand the environmental justice movement's conceptual reach in the modern context. The link between climate change, energy, and environmental justice is unmistakable: the energy sector contributes to climate change more than any other industry; climate change is predicted to affect environmental justice communities most; and the energy sector has a long history with environmental injustice. The chapter provides practical guidance on integrating environmental justice principles into the law and policy governing the renewable energy transition.

Building on Outka's chapter, Carmen G. Gonzalez's chapter, "An environmental justice critique of biofuels" (Chapter 3), examines the intersection of environmental justice and energy justice at the international level in the context of biofuels law and policy. Replacing fossil fuels with biofuels derived from renewable organic matter has been promoted as a means of mitigating climate change, achieving energy security, and fostering economic development in the countries that produce the crops used as biofuel feedstocks. The chapter examines the impact of the laws and policies driving the biofuels boom, and concludes that they have contributed to global malnourishment by raising food prices and have accelerated the large-scale acquisition of arable lands in poor countries that displace vulnerable local communities (a phenomenon known as land-grabbing). To add insult to injury, many of these biofuels (including corn-based ethanol) emit more greenhouse gases than the fossil fuels they replace, and degrade soil and water in the countries

16 Notably, while this linkage is highly relevant within the United States, the environmental justice framework is only one of many discourses adopted by grassroots social movements in other parts of the world. See, e.g., Tracy-Lynn Humby, Evaluating the Value of TWAIL, Environmental Justice, and Decolonization Discourses as Framing Lenses for International Environmental Law, 26 Transnat'L L. \& Contemp. Probs. 317, 339 (2017); $c f$. Joan Martinez-Alier et al., Is There a Global Environmental Justice Movement?, 43 J. PEASANT STUD. 731, 748 (2016). 
where biofuel feedstocks are cultivated. The chapter discusses governance strategies to foster a more equitable and sustainable approach to bioenergy.

\section{INTERSECTION WITH HUMAN RIGHTS}

Recognizing the importance of human rights-based approaches to energy law and policy, the book also considers the relationship between human rights law and energy justice. The concept of energy justice can expand the human rights framework. While there is currently no stand-alone right to energy, access to energy is essential for the fulfillment of other human rights, including the right to health, food, water, and an adequate standard of living. ${ }^{17}$ Accordingly, the two are intertwined, and the energy justice movement can create the impetus to expand our understanding of human rights law.

The connection between human rights law and energy justice is explored in Damilola Olawuyi's chapter, "Energy (and human rights) for all: addressing human rights risks in energy access projects" (Chapter 4). Lack of access to energy exacerbates other social challenges, including poverty, food insecurity, inadequate access to clean water, poor health, and stunted economic growth. However, many projects designed to promote access to both renewable and non-renewable energy, such as biofuel projects in Indonesia; nuclear power plant projects in Nigeria; hydroelectric projects in China, Panama, and Honduras; and the West African Gas Pipeline project in Nigeria and Ghana, have been plagued by human rights violations. The chapter examines law and governance innovations required to address human rights risks in energy access projects, including practical tools to incorporate human rights safeguards into national energy law and policy.

\section{INTERSECTION WITH CLIMATE JUSTICE}

Next, the book considers how energy justice intersects with principles developed in the climate justice movement. The 2015 landmark UN Climate Agreement in Paris has propelled energy regulation into the limelight as a means of reducing global greenhouse gas emissions so as

17 See Carmen G. Gonzalez, Energy Poverty and the Environment, in LAKSHMAn Guruswamy, InTERnATIONAL ENERGy AND POVERTY: THE EMERGING CONTOURS 121-23 (2016). 
to avert climate catastrophe. One of the challenges facing the international community is how to reconcile climate change mitigation with international commitments to eradicate energy poverty. ${ }^{18}$ Energy law and regulation to fairly facilitate universal access to safe, affordable, and reliable power, sustainably and restoratively_or "energy justice"provides a solution to this conundrum.

A cornerstone of any climate change mitigation strategy is the transition away from fossil fuels by both current and future energy users. Climate justice requires that the countries responsible for the largest share of greenhouse gas emissions take the lead in addressing climate change. Many developed nations have enacted domestic regulatory programs designed to curb greenhouse gas emissions and promote clean and renewable energy. These efforts, by the nations that have historically contributed most to climate change, must improve and advance.

Roger Colton's chapter, "The equities of efficiency: distributing energy usage reduction dollars" (Chapter 5), recognizes this trend and discusses how using energy more efficiently is one of the most effective ways to address climate change, reduce dependence on fossil fuels, and promote energy justice. Energy efficiency has the advantage of reducing all types of power plant-related emissions simultaneously by avoiding the need to generate electricity in the first place. It thereby mitigates climate change while improving air quality in the communities most burdened by air pollution. Energy efficiency is a well-established industry in the United States with billions of dollars invested annually through administered energy efficiency services programs, energy savings performance contracting, and other efforts.

The chapter offers a definition of "equity" in the context of the distribution of utility investments. It then describes an original mechanism, first applied to issues of equity in non-energy industries, that can be adapted to objectively measure the fairness of utility usage reduction investments in a particular application and set of circumstances. This chapter presents a first of its kind tool to measure equity in multifamily energy efficiency investments.

\section{INTERSECTION WITH INDIGENOUS RIGHTS}

Indigenous peoples in many nations disproportionately bear the impacts of energy development. However, the majority of these communities

\footnotetext{
18 See ibid. at 113.
} 
contribute little, if anything, to the negative externalities of such development and seldom benefit from energy projects. As a result, issues of energy justice often pervade energy development near indigenous communities. Recognizing this trend, several chapters explore concepts of energy justice within indigenous communities.

Jeanette Wolfley's chapter, "Mni Wiconi, tribal sovereignty, and treaty rights: lessons from the Dakota Access Pipeline" (Chapter 6), examines how energy projects are impacting indigenous communities, with a specific focus on tribes in the United States. The chapter analyzes the controversial Dakota Access Pipeline (DAPL) to demonstrate the continuing importance of treaty rights and sovereignty of Indian nations in the United States, and the growing opposition to oil and gas pipeline construction near tribal lands. The increase in energy development and renewal of existing rights-of-way promises to lead to more clashes in the coming years. The chapter argues that it is, therefore, imperative for the energy industry to seriously deliberate the lessons learned from the DAPL standoff, and to pursue meaningful and respectful engagement with affected communities.

Building on these themes, Catherine J.K. Sandoval's chapter, "Energy access is energy justice: the Yurok Tribe's trail-blazing work to close the Native American reservation electricity gap" (Chapter 7), examines the roots of energy poverty in Native American reservations through a case study of the Yurok Tribe's path-breaking work to extend the electric grid to the Yurok Reservation in northern California. The chapter analyzes the federalist framework that contributes to the Native American electricity access gap. Since 1935 when Congress passed the Federal Power Act, the federal government has been responsible for interstate transmission and wholesale energy market regulation. However, the federal government has not assumed responsibility for funding the electric distribution infrastructure necessary to supply electricity to Native American tribes. The chapter argues that the federal government's failure to provide safe, reliable, and sustainable energy access on Native American reservations is incompatible with existing federal policy and law. The chapter concludes with practical recommendations to foster electric grid expansion to Native American reservations consistent with both federal and state law and policy priorities.

Finally, Dayna Nadine Scott's and Adrian A. Smith's chapter, "Transforming relations in the green energy economy: control of lands and livelihoods" (Chapter 8), presents a tale of two indigenous communities in Canada-one that faced the devastating impacts of energy development and another that has successfully developed a sustainable energy project under its inherent sovereignty. The chapter examines the plight of 
communities displaced by "green energy" projects designed to address climate change, such as solar, wind, nuclear, and hydroelectric projects. Despite these projects' devastating human rights impacts (such as loss of land, forced migration, and destruction of subsistence livelihoods), many are proceeding full steam ahead, buoyed by growing enthusiasm for green energy. Indeed, planned relocation strategies developed for those fleeing the destruction of their homes by climate change are being proposed as solutions for communities displaced by green energydisregarding the meaningful spiritual and cultural connections that many people develop with specific lands, species, and ecosystems. The chapter serves as a warning that the power dynamics of the green economy may reproduce the "sacrifice zones" of the fossil fuel economy.

\section{ENERGY JUSTICE AND ENERGY DEMOCRACY}

Two chapters in the book address the relatively new concept of "energy democracy," which integrates "policies linking social justice[, energy ownership,] and economic equity with renewable energy transitions."19 In the context of distributed generation, energy democracy seeks to deconstruct the model of the utility as a "natural monopoly"20 and replace it with more participatory structures. Such structures could include, for example, the re-municipalization of a privately owned energy system ${ }^{21}$ or the construction of a community owned solar farm. ${ }^{22}$ In this way, energy democracy is similar to the concept of energy sovereignty, which envisions a "right" of peoples and communities to make their own

19 See Matthew J. Burke and Jennie C. Stephens, Energy Democracy: Goals and Policy Instruments for Sociotechnical Transitions, 33 ENERGY RES. \& Soc. SCI. 35, 35 (2017).

20 For a discussion of public utilities and natural monopoly, see Richard A. Posner, Natural Monopoly and Its Regulation, 21 STAN. L. REV. 548 (1968), available at https://chicagounbound.uchicago.edu/cgi/viewcontent.cgi?referer= http://scholar.google.com/\&httpsredir=1\&article=2861\&context=journal_articles.

21 In "a 2011 voter ballot initiative, the City of Boulder, Colorado formally launched a process of remunicipalization." Burke and Stephens, Energy Democracy, supra note 19 , at 41.

22 Energy democracy's proponents cover the political spectrum and do not necessarily espouse "democracy" as a pure political form. Some supporters of, for example, remunicipalization may make no call for social equity. Another advocate for a community owned energy system may adhere to socialist principles. We expect these issues to be explored further as the energy democracy concept develops. 
decisions on energy systems that are in line with their own circumstances. ${ }^{23}$ Both concepts explore the boundaries of utility ownership paradigms and the traditional notion that utilities are fossil fuel based.

Shalanda Baker's chapter, "Emerging challenges in the global energy transition: a view from the frontlines" (Chapter 9) considers, through an energy democracy framework, how indigenous communities in Mexico are being impacted by renewable energy investments by private capital from the Global North sparked, in large part, by Mexico's marketoriented energy transition. The renewable energy transition unfolding in Mexico provides a preview of what private-led renewable energy development might look like across the Global South, as well as the inherent tensions of doing business in a country that is still home to millions of indigenous peoples. Indeed, countries throughout the Global South, such as Brazil, are closely watching Mexico's market-driven reforms to determine whether they can be replicated. This chapter provides a window into emerging tensions resulting from this development path and explores how these tensions might be resolved utilizing an energy democracy framework.

Eleanor Stein's chapter, "Energy democracy: power to the people? An introduction" (Chapter 10), examines the contours of energy democracy. The chapter discusses how energy democracy has emerged in the American energy policy space as both a relatively new concept and a rallying cry. The energy democracy movement developed in Europe and has gained popularity in the United States as communities have sought to exert self-determination over their energy systems. Energy democracy, however, also has a broader meaning. It encompasses the struggle against the corporate ownership of socially vital and environmentally strategic resources in favor of democratically controlled and socially owned energy. The chapter notes, however, that democratically controlled or owned utility systems do not necessarily result in social justice or equity. Through a case study of the Reforming the Energy Vision initiative in New York State, the chapter illustrates the ways in which grassroots movements are increasingly seeking both control over energy decisionmaking and also ownership of the energy infrastructure itself.

23 Pere Ariza-Montobbio, Energy Sovereignty: Politicizing an Energy Transition, ENVTL. JuS. ORGS., LIABS. \& TRADE 79, 79 (2015), available at www.ejolt. org/wordpress/wp-content/uploads/2015/09/EJOLT-6.79-84.pdf. 


\section{CONCLUSION}

Energy is a complex and interdisciplinary area of study. Energy justice cannot avert climate change on its own. Climate mitigation cannot occur without addressing energy use on a grand scale. Yet issues of equity, justice, and fairness pervade both energy and climate law and policy.24

Ultimately, through the chapters in this book, we hope to further theorize energy justice, while also illustrating with concrete examples the ways that theory may be put into practice. The book demonstrates how energy law becomes energy justice when scholars, policy-makers, and activists apply to energy the justice frameworks developed by communities in struggle: environmental justice, human rights, climate justice, and indigenous rights. It also invites further engagement with the emerging concept of energy democracy. We encourage the exploration of these linkages and others as the field of energy justice expands and moves forward.

24 Intergovernmental Panel on Climate Change, Climate Change 2014 Mitigation of Climate Change: Summary for PolicymaKers TeChNICAL SUMMARY: PART OF THE WORKING GROUP III CONTRIBUTION TO THE Fifth Assessment Report of the InTERgovernmental PANEL ON Climate CHANGE 5 (2014), available at www.ipcc.ch/pdf/assessment-report/ar5/wg3/ WGIIIAR5_SPM_TS_Volume.pdf. 